\title{
Reptilia, Squamata, Gymnophthalmidae, Heterodactylus imbricatus Spix, 1825: Filling gaps in the state of Minas Gerais
}

\author{
Iara Alves Novelli*, Priscila da Silva Lucas and Rodrigo Costa Santos \\ Centro Universitário de Lavras (UNILAVRAS), Laboratório de Zoologia. R. Padre José Poggel, 506, Centenário. CEP 37200-000. Lavras, MG, Brasil. \\ * Corresponding author. E-mail: iaranovelli27@gmail.com
}

\begin{abstract}
Heterodactylus imbricatus occurs in southeastern of Brazil in areas of high altitude Atlantic rainforest. We collect one adult female and one adult male of this species in Reserva Biológica Unilavras - Boqueirão, in municipality of Ingaí (MG). The habitat encompasses riparian forest associated with Cerrado biome.
\end{abstract}

The genus Heterodactylus comprise three species of lizards, all of them with distribution range restricted to Brazil: Heterodactylus imbricatus Spix, 1825; Heterodactylus lundii Reinhardt and Lutken, 1862; and Heterodactylus septentrionalis Rodrigues, Freitas and Silva 2009 (Rodrigues et al. 2009; Bérnils 2010).

Heterodactylus imbricatus is a Gymnophthalmidae that occurs in southeastern Brazil (Minas Gerais, Rio de Janeiro, São Paulo and Espírito Santo states), in high altitude areas of Atlantic Rainforest domain (Von Hering 1898; Rocha et al. 2004; Sendas and Araújo 2004; Dixo and Verdade 2006; Rodrigues et al. 2007; 2009; Dixo and Metzger 2009; Marques et al. 2009).

On 7 November 2008 and 17 September 2009, one adult female (6.14 mm snout-vent length; Figure 1) and one adult male $(9.68 \mathrm{~mm}$ snout-vent length; Figure 2) Heterodactylus imbricatus were collect in Reserva Biológica Unilavras - Boqueirão (RBUB) (2120'47” S, 4459'27" W, 1,250 m elevation) (Figure 3) municipality of Ingaí, state of Minas Gerais (permits: SISBI0/14740-1,

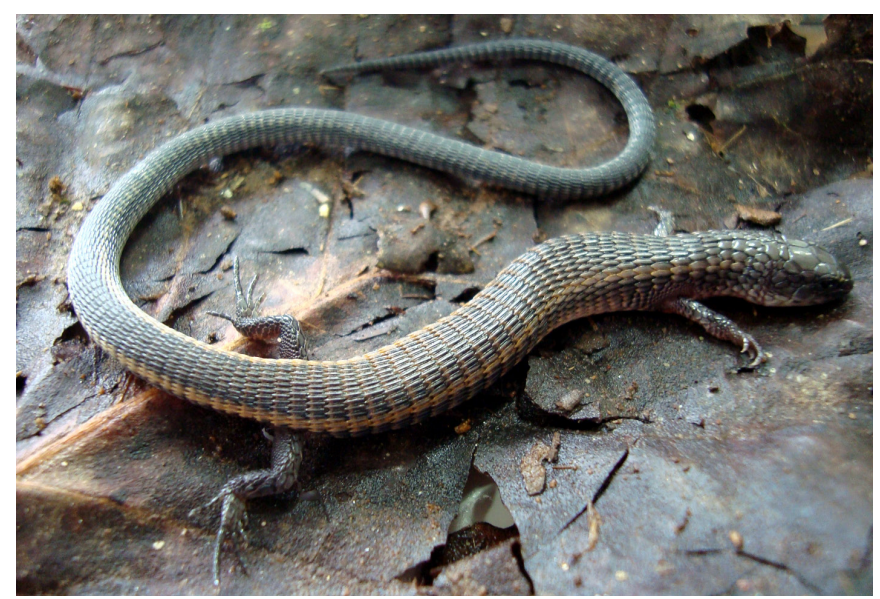

FIGURE 1. Adult female Heterodactylus imbricatus (CRLZ 000074) from the Reserva Biológica do Unilavras - Boqueirão, municipality of Ingaí, state of Minas Gerais. Photo by R. C. Santos.

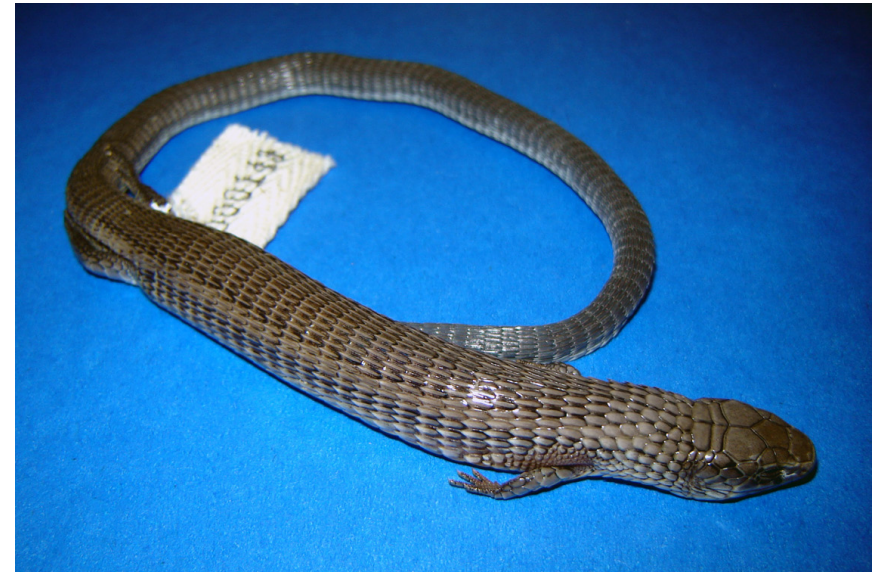

FIGURE 2. Adult male Heterodactylus imbricatus (CRLZ 000143) from the Reserva Biológica do Unilavras - Boqueirão, municipality of Ingaí, state of Minas Gerais. Photo by I. A. Novelli.

register 1971350). The habitat encompasses riparian forest associated with physiognomies of Cerrado.

This species was previously registered in the state of Minas Gerais in the municipalities of Santa Bárbara, Alfenas, Itabira, Itabirito, Lambari, Mariana, Rio Preto, Poços de Caldas, São Gonçalo do Sapucaí and São Pedro do Piqueri (Figure 4) (Rodrigues et al. 2007, 2009). The record here reported represents a filling gap in the geographical distribution of $H$. imbricatus in the state of Minas Gerais.

In despite of previous registers of $H$. imbricatus in areas of Atlantic Rainforest (Rocha et al. 2004; Sendas and Araújo 2004; Dixo and Verdade 2006; Gonçalves et al. 2007; Rodrigues et al. 2009; Dixo and Metzger 2009; Marques et al. 2009) the specimens of the current study were collected in a riparian forest in a Cerrado habitat. This fact highlights the importance of forest fragments associated to Cerrado domain on the distribution of this lizard species. Voucher specimens (CRLZ 000074, 000143) were deposited at the Coleção de Répteis do Laboratório de Zoologia, Centro Universitário de Lavras - Unilavras, municipality of Lavras, state of Minas Gerais, Brazil. 


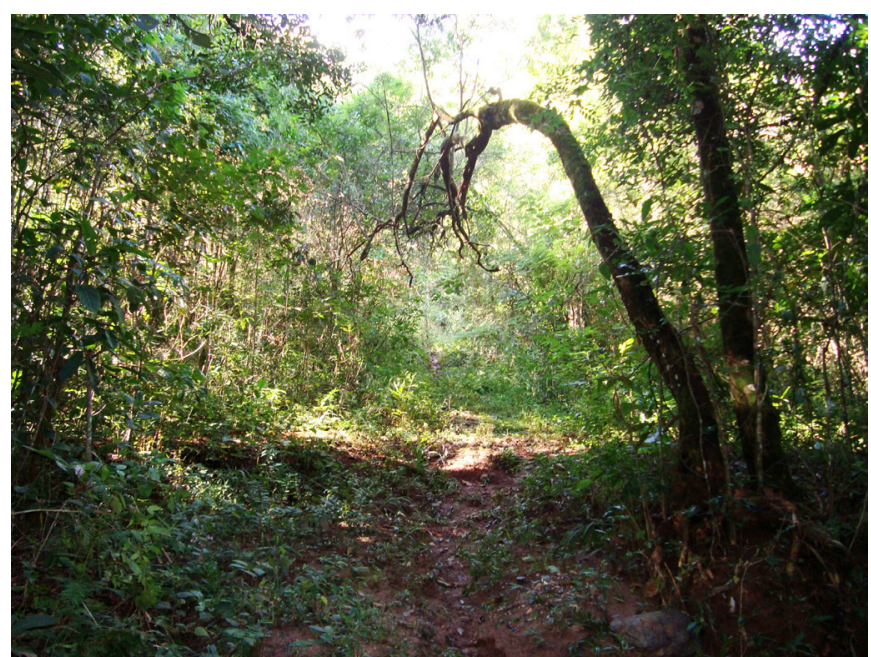

FIGURE 3. Study area, located in the Reserva Biológica do Unilavras Boqueirão, municipality of Ingaí, state of Minas Gerais. Photo by R. C. Santos.

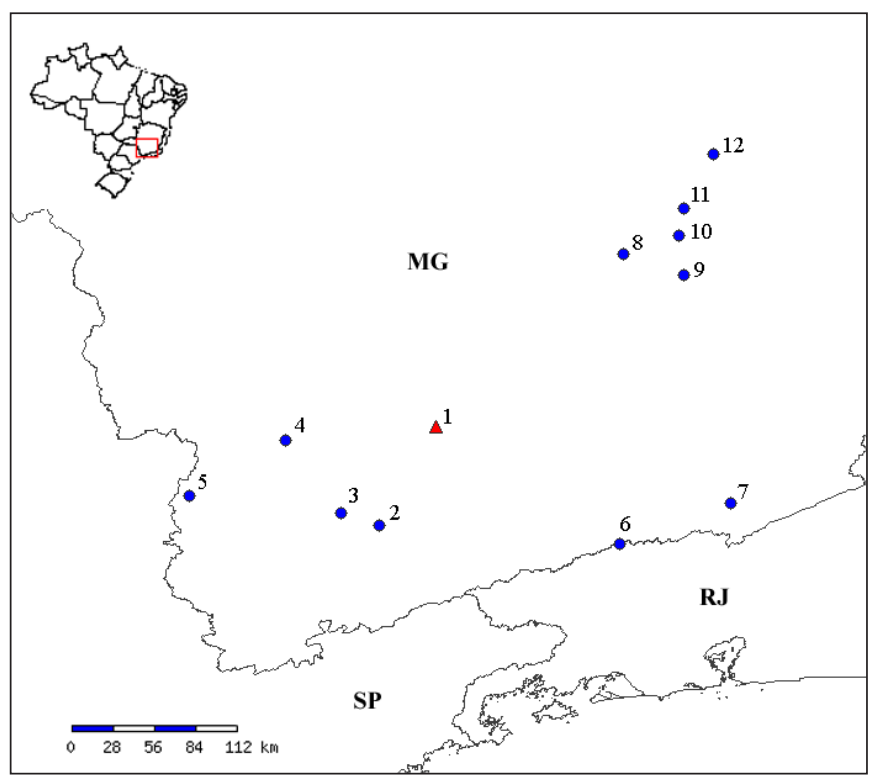

FIGURE 4. Known distribution of Heterodactylus imbricatus in the state of Minas Gerais. Blue circles = literature registers; red triangle = present register. 1. Reserva Biológica do Unilavras, municipality of Ingaí; 2. Parque Estadual Nova Baden, municipality of Lambari; 3. municipality of São Gonçalo do Sapucaí; 4. municipality of Alfenas; 5. municipality of Poços de Caldas; 6. municipality of Rio Preto; 7. municipality of Pequeri (previously known as São Pedro do Pequeri); 8. municipality of Itabirito; 9. municipality of Mariana; 10. District of Santa Rita Durão, municipality of Mariana; 11. Serra do Caraça, municipality of Santa Bárbara; 12. municipality of Itabira) (MG = Minas Gerais state; $\mathrm{SP}=$ São Paulo state; $\mathrm{RJ}=$ Rio de Janeiro state).
ACKNowledgments: We thank to Prof. Dr. Fernando Antônio FrieiroCosta, and Fabiano B. Silva for logistical support. RCS was supported by a student fellowship from PROBIC/FAPEMIG/UNILAVRAS.

\section{Literature Cited}

Bérnils, R.S. 2010. Brazilian reptiles - List of species. Electronic database accessible at http://www.sbherpetologia.org.br/. Sociedade Brasileira de Herpetologia. Captured on 20 July 2010.

Dixo, M. and J.P. Metzger. 2009. Are corridors, fragment size and forest structure important for the conservation of leaf-litter lizards in a fragment landscape? Fauna and Flora International, Oryx 43(3): 435442.

Dixo, M. and V.K. Verdade. 2006. Herpetofauna de Serrapilheira da Reserva Florestal de Morro Grande, Cotia (SP). Biota Neotropica 6(2): 1-20.

Marques, O.A.V., D.N. Pereira, F.E. Barbo, V.J. Germano and R.J. Sawaya 2009. Os répteis do Município de São Paulo: diversidade e ecologia da fauna pretérita e atual. Biota Neotropica 9(2): 1-12.

Rocha, C.F.D., H.G. Bergallo, J.P. Pombal Jr., L. Geise, M. Van Sluys, R. Fernades and U. Caramaschi. 2004. Lista de anfíbios, répteis e mamíferos do Estado do Rio de Janeiro, Sudeste do Brasil. Publicações Avulsas do Museu Nacional 104: 1-24.

Rodrigues, M.T., K.C.M. Pellegrino, M. Dixo, V.K. Verdade, D. Pavan, A.J.S. Argolo and J.W. Sites Jr. 2007. A new genus of Microteiid Lizard from the Atlantic Forests of State Bahia, Brazil, with a New Generic Name for Colobosaura mentalis mentalis, and a Discussion of Relationships Among the Heterodactylini (Squamata, Gymnophthalmidae). American Museum Novitates 3565: 1-27.

Rodrigues, M.T., M.A. Freitas and T.F.S. Silva. 2009. New Species of Earless Lizard Genus Heterodactylus (Squamata: Gymnophthalmidae) from the Highlands of Chapada Diamantina, State of Bahia, Brazil. Journal of Herpetology 43(4): 605-611.

Sendas, F.A. and A.F.B. Araújo. 2004. Inventário preliminar dos Répteis do Parque Nacional do Itatiaia (PNI), Rio de Janeiro. Revista Universidade Rural 24(2): 151-157.

Von Hering, H. 1898. Contributions to the herpetology of Sao Paulo, Brazil: I. Proceedings of the Academy of Natural Sciences of Philadelphia 50: 101-109.

RECEIVED: February 2010

LAST REVISED: December 2010

ACCEPTED: December 2010

Published online: January 2011

EDITORIAL RESPONSIBILITY: Alexandro Marques Tozetti 